Prepared in cooperation with the National Water-Quality Assessment Program

\title{
Estimates for Self-Supplied Domestic Withdrawals and Population Served for Selected Principal Aquifers, Calendar Year 2005
}

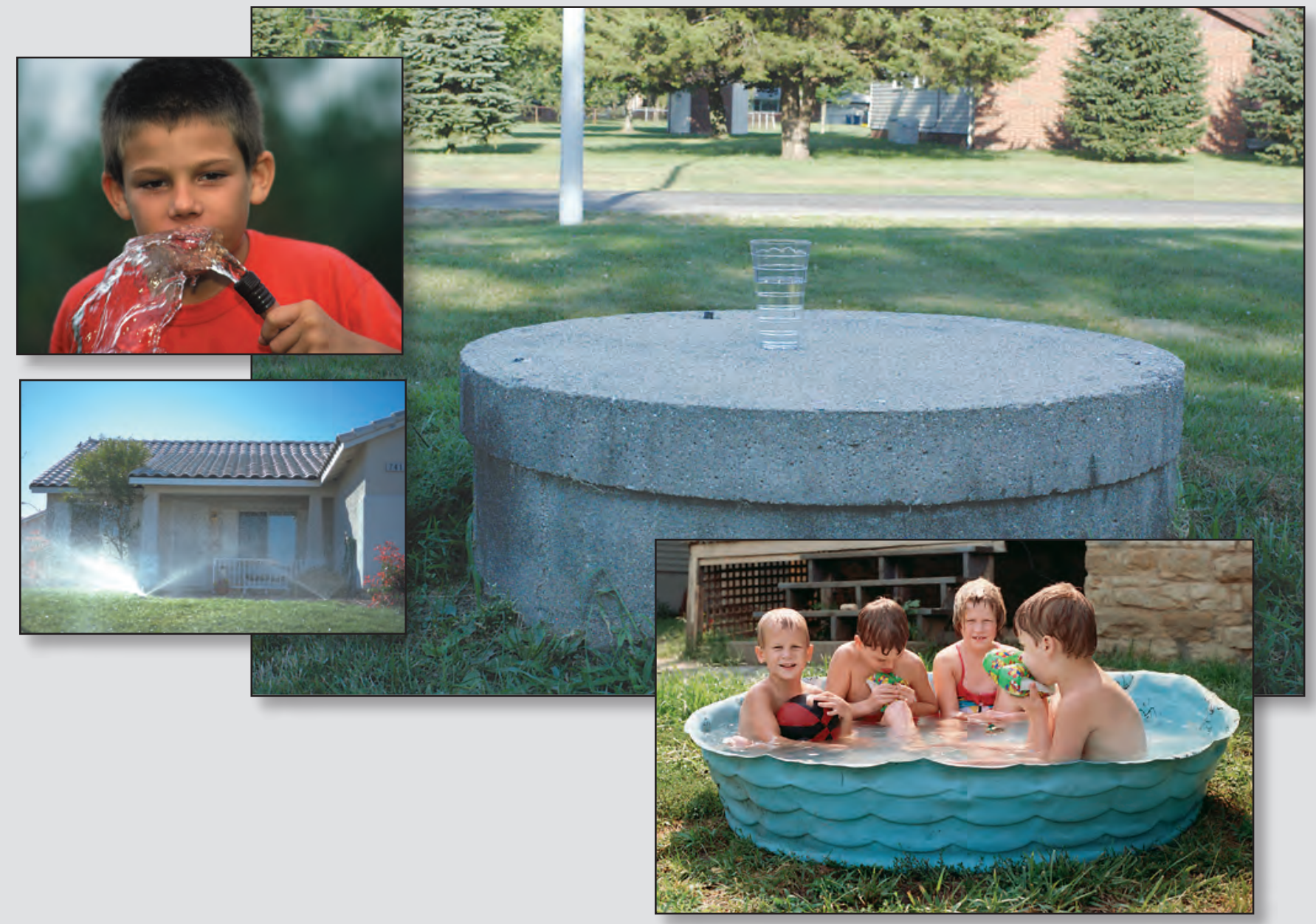

Open-File Report 2010-1223 



\section{Estimates for Self-Supplied Domestic Withdrawals and Population Served for Selected Principal Aquifers, Calendar Year 2005}

By Molly A. Maupin and Terri L. Arnold

Prepared in cooperation with the National Water-Quality Assessment Program

Open-File Report 2010-1223 


\title{
U.S. Department of the Interior \\ KEN SALAZAR, Secretary
}

\section{U.S. Geological Survey \\ Marcia K. McNutt, Director}

\section{U.S. Geological Survey, Reston, Virginia: 2010}

\author{
For more information on the USGS — the Federal source for science about the Earth, its natural and living resources, \\ natural hazards, and the environment, visit http://www.usgs.gov or call 1-888-ASK-USGS \\ For an overview of USGS information products, including maps, imagery, and publications, \\ visit http://www.usgs.gov/pubprod \\ To order this and other USGS information products, visit http://store.usgs.gov
}

Any use of trade, product, or firm names is for descriptive purposes only and does not imply endorsement by the U.S. Government.

Although this report is in the public domain, permission must be secured from the individual copyright owners to reproduce any copyrighted materials contained within this report.

Suggested citation:

Maupin, M.A., and Arnold, T.L., 2010, Estimates for self-supplied domestic withdrawals and population served for selected principal aquifers, calendar year 2005: U.S. Geological Survey Open-File Report 2010-1223, 10 p. 


\section{Foreword}

The U.S. Geological Survey (USGS) is committed to providing the Nation with reliable scientific information that helps to enhance and protect the overall quality of life and that facilitates effective management of water, biological, energy, and mineral resources (http://www.usgs.gov). Information on the Nation's water resources is critical to ensuring long-term availability of water that is safe for drinking and recreation and is suitable for industry, irrigation, and fish and wildlife. Population growth and increasing demands for water make the availability of that water, now measured in terms of quantity and quality, even more essential to the long-term sustainability of our communities and ecosystems.

The USGS implemented the National Water-Quality Assessment (NAWQA) Program in 1991 to support national, regional, state, and local information needs and decisions related to water-quality management and policy (http://water.usgs.gov/nawqa). The NAWQA Program is designed to answer: What is the quality of our Nation's streams and ground water? How are conditions changing over time? How do natural features and human activities affect the quality of streams and ground water, and where are those effects most pronounced? By combining information on water chemistry, physical characteristics, stream habitat, and aquatic life, the NAWQA Program aims to provide science-based insights for current and emerging water issues and priorities. From 1991 to 2001, the NAWQA Program completed interdisciplinary assessments and established a baseline understanding of water-quality conditions in 51 of the Nation's river basins and aquifers, referred to as Study Units (http://water.usgs.gov/nawqa/ studyu.html).

National and regional assessments are ongoing in the second decade (2001-2012) of the NAWQA Program as 42 of the 51 Study Units are reassessed. These assessments extend the findings in the Study Units by determining status and trends at sites that have been consistently monitored for more than a decade, and filling critical gaps in characterizing the quality of surface water and ground water. For example, increased emphasis has been placed on assessing the quality of source water and finished water associated with many of the Nation's largest community water systems. During the second decade, NAWQA is addressing five national priority topics that build an understanding of how natural features and human activities affect water quality, and establish links between sources of contaminants, the transport of those contaminants through the hydrologic system, and the potential effects of contaminants on humans and aquatic ecosystems. Included are topics on the fate of agricultural chemicals, effects of urbanization on stream ecosystems, bioaccumulation of mercury in stream ecosystems, effects of nutrient enrichment on aquatic ecosystems, and transport of contaminants to public-supply wells. In addition, national syntheses of information on pesticides, volatile organic compounds (VOCs), nutrients, selected trace elements, and aquatic ecology are continuing.

The USGS aims to disseminate credible, timely, and relevant science information to address practical and effective water-resource management and strategies that protect and restore water quality. We hope this NAWQA publication will provide you with insights and information to meet your needs, and will foster increased citizen awareness and involvement in the protection and restoration of our Nation's waters.

The USGS recognizes that a national assessment by a single program cannot address all water-resource issues of interest. External coordination at all levels is critical for cost-effective management, regulation, and conservation of our Nation's water resources. The NAWQA Program, therefore, depends on advice and information from other agencies—Federal, state, regional, interstate, Tribal, and local—as well as nongovernmental organizations, industry, academia, and other stakeholder groups. Your assistance and suggestions are greatly appreciated. 
This page left intentionally blank 


\section{Contents}

Abstract

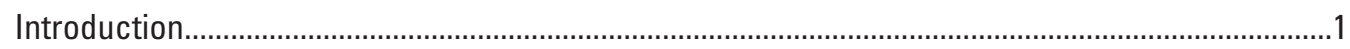

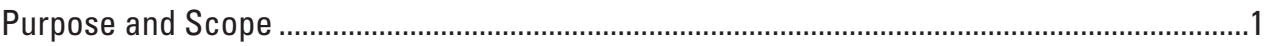

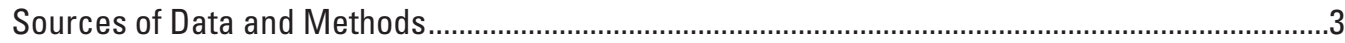

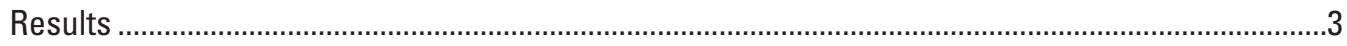

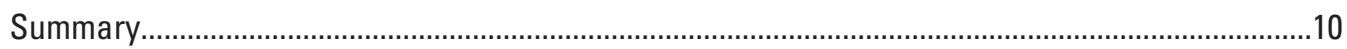

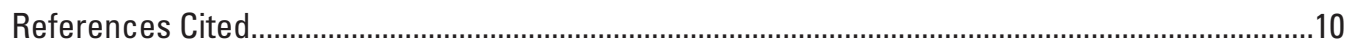

\section{Figures}

Figure 1. Map showing location and extent of the principal aquifers for regional assessment as part of the National Water-Quality Assessment Program .......... 2

Figure 2. Map showing counties lacking domestic well information in the U.S. Geological Survey National Water Information System (NWIS) database as of April 2009

\section{Tables}

Table 1. Summary of total self-supplied domestic groundwater withdrawals and total population served for 20 aquifers during calendar year 2005

Table 2. Estimated self-supplied domestic groundwater withdrawals by state and aquifer for calendar year 2005

Table 3. Estimated self-supplied domestic population served by state and aquifer for calendar year 2005 


\section{Conversion Factors, and Abbreviations and Acronyms}

Conversion Factors
\begin{tabular}{lll} 
Inch/Pound to SI & & \\
\hline \multicolumn{1}{c}{ Multiply } & By & \multicolumn{1}{c}{ To obtain } \\
\hline gallon (gal) & 3.785 & liter $(\mathrm{L})$ \\
million gallons per day (Mgal/d) & 0.04381 & cubic meter per second $\left(\mathrm{m}^{3} / \mathrm{s}\right)$ \\
\hline
\end{tabular}

$\begin{array}{ll}\text { Abbreviations and Acronyms } \\ \text { NWIS } & \text { National Water Information System } \\ \text { NAWQA } & \text { National Water-Quality Assessment Program } \\ \text { NWUIP } & \text { National Water Use Information Program } \\ \text { USGS } & \text { U.S. Geological Survey } \\ \text { WSC } & \text { Water Science Center }\end{array}$




\title{
Estimates for Self-Supplied Domestic Withdrawals and Population Served, for Selected Principal Aquifers, Calendar Year 2005
}

\author{
By Molly A. Maupin and Terri L. Arnold
}

\begin{abstract}
The National Water-Quality Assessment Program of the U.S. Geological Survey has groundwater studies that focus on water-quality conditions in principal aquifers of the United States. The Program specifically focuses on aquifers that are important to public supply, domestic, and other major uses. Estimates for self-supplied domestic withdrawals and the population served for 20 aquifers in the United States for calendar year 2005 are provided in this report. These estimates are based on county-level data for self-supplied domestic groundwater withdrawals and the population served by those withdrawals, as compiled by the National Water Use Information Program, for areas within the extent of the 20 aquifers. In 2005, the total groundwater withdrawals for selfsupplied domestic use from the 20 aquifers represented about 63 percent of the total self-supplied domestic groundwater withdrawals in the United States; the population served by the withdrawals represented about 61 percent of the total selfsupplied domestic population in the United States.
\end{abstract}

\section{Introduction}

The National Water-Quality Assessment (NAWQA) Program of the U.S. Geological Survey (USGS) focuses its groundwater studies on water-quality conditions, including status and trends in principal aquifers of the United States, and specifically those aquifers important to public supply and domestic uses (Lapham and others, 2005; National Water-Quality Assessment Program, 2010) (fig. 1). NAWQA studies need accurate, current data about the amount of water withdrawn from these aquifers and the size of the Nation's population that relies on them.

The USGS Office of Groundwater identified more than 60 principal regional aquifers in the United States (U.S. Geological Survey, 2003), some of which are major sources of water for drinking-water supplies. Estimates of groundwater withdrawals for three major water uses (public supply, self-supplied industrial, and irrigation) were compiled for each of these principal aquifers using 2000 data (Maupin and Barber, 2005); however, groundwater withdrawal data for the population served by those withdrawals do not exist for self-supplied domestic use by principal aquifer. Selfsupplied domestic withdrawals are derived from private wells for domestic indoor and outdoor use, as compared to public-supply withdrawals, which are derived from public water systems and are used for public, domestic (homes on public-supply systems), commercial, and industrial purposes. This study used 2005 county-level self-supplied domestic groundwater withdrawals and the population served by those withdrawals from the USGS National Water Use Information Program (NWUIP) as the source data to allocate withdrawals and population served to 20 selected principal aquifers (fig. 1). Some of the principal aquifers were combined for this study; for example, the sand and gravel aquifers north of the limit of Quaternary continental glaciations and east of the Rocky Mountains (hereinafter referred to as Glacial aquifer system) also include aquifers denoted as 'Unconsolidated-deposit aquifers (Alaska)' and 'Puget Sound aquifer system' as shown in the National Atlas (U.S. Geological Survey, 2003).

Groundwater is the primary source of water for selfsupplied domestic use. In 2005, groundwater withdrawals for self-supplied domestic use in the United States were an estimated 3,740 Mgal/d (million gallons per day) (Kenny and others, 2009), which comprised 98 percent of the total self-supplied domestic withdrawals in the Nation (2 percent of withdrawals were from surface-water sources). An estimated 42.9 million people in the United States, or 14 percent of the total population, supplied themselves with water obtained from private wells.

\section{Purpose and Scope}

This report summarizes estimates of groundwater withdrawals for self-supplied domestic use and the population served by those withdrawals from 20 aquifers in the United States during calendar year 2005 (fig. 1). This report also explains the different sources of data and the methods that were used to derive the groundwater withdrawals and population served. These data were compiled as part of the NAWQA principal aquifers studies using data from 


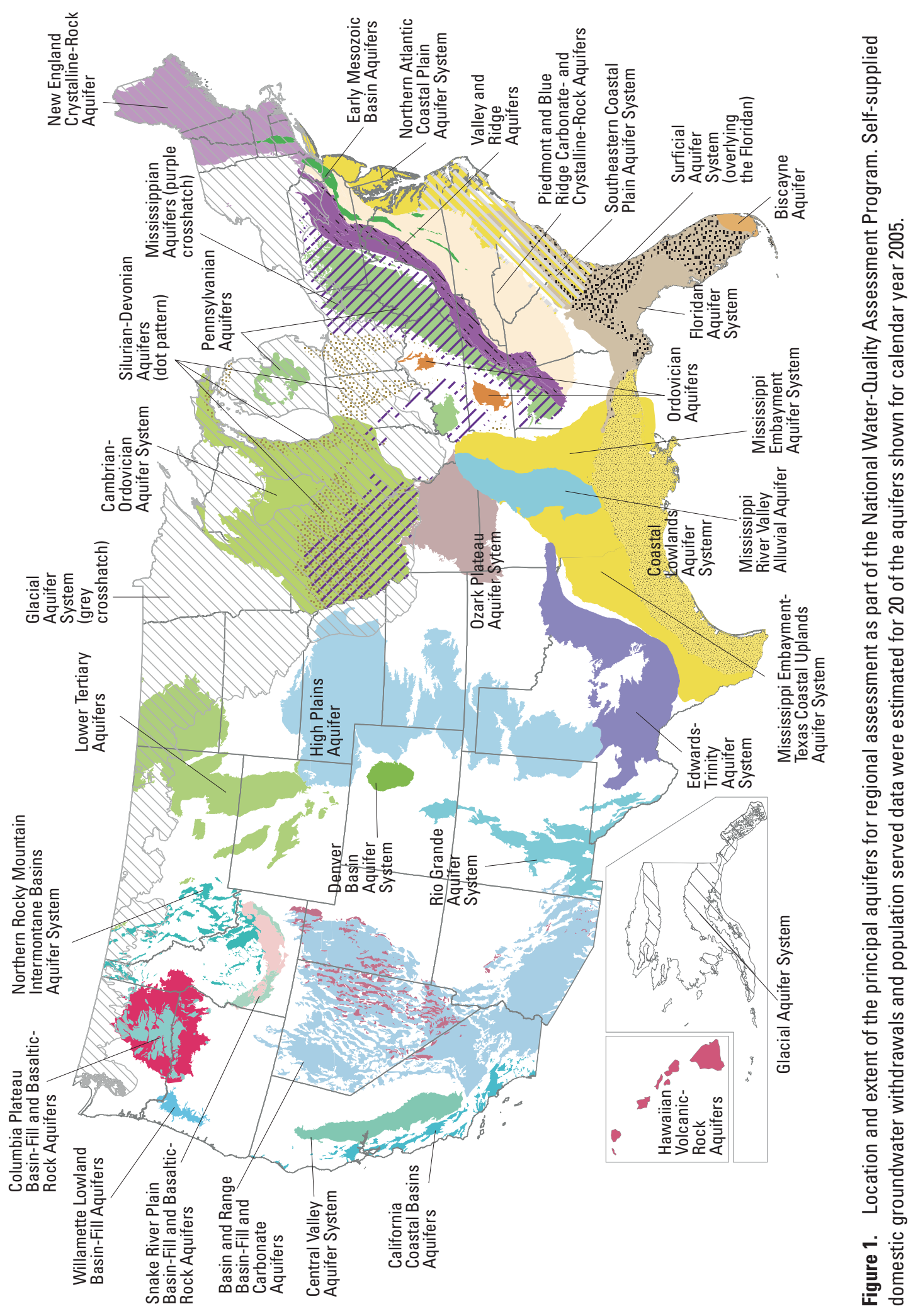


the NWUIP's 5-year county dataset for 2005, or other data provided by water-use specialists in USGS Water Science Centers. Data were compiled for 20 aquifers or aquifer groups (some principal aquifers were combined), which represents a subset of the more than 60 principal aquifers as shown on the USGS principal aquifer map of the National Atlas of the United States (U.S. Geological Survey, 2003). The data represent groundwater withdrawals for calendar year 2005 in $\mathrm{Mgal} / \mathrm{d}$, and population served, in thousands of people.

\section{Sources of Data and Methods}

County groundwater data are compiled by each USGS Water Science Center (WSC) every 5 years as part of the NWUIP. The most recent compilation at the time this study was conducted was for calendar year 2005. Data for counties within the areal extent of the selected aquifers were compiled to create the initial dataset of self-supplied domestic groundwater withdrawals and the population served by those withdrawals (http://water.usgs.gov/watuse/data/2005/ index.html). Water-use specialists in a few WSCs provided domestic withdrawals and population data by principal aquifer for the states in which they are located. Withdrawals and the population served by those withdrawals, by aquifer, were supplied for Florida, New Jersey, Oklahoma, Vermont, Virginia, and Wisconsin; only withdrawals were provided for Georgia, Illinois, Indiana, Louisiana, Michigan, Missouri, Tennessee, and West Virginia. Withdrawal and population served data for all other states that did not provide data were allocated to the 20 aquifers either using USGS database information regarding the number of domestic wells and aquifer sources in each county, or using maps showing the areal extent of the aquifers.

Data provided directly from WSCs were initially compiled by WSC water-use specialists using methods and techniques that followed guidelines for the 2005 national water-use compilation (Hutson, 2007). Groundwater withdrawals and population data were allocated to the 20 aquifers either as part of the 2005 compilation (Marella, 2009; Tortorelli, 2009), or using methods developed from other studies that focused on similar goals (Pope and others, 2008). All data were checked for consistency and accuracy by WSC water-use specialists.

If withdrawal and population served data were not provided by a WSC, it was interpolated using USGS databases and geographic analysis of the areal extent of the 20 aquifers. Each WSC maintains well information in a database system common to all USGS offices in the United States, the National Water Information System (NWIS). NWIS stores information about wells used for many purposes, but this study specifically focused on domestic wells. Well information in NWIS includes location, depth of well, water use and water levels, and some aquifer information. A retrieval of all domestic wells in NWIS databases for 48 States (excluding Alaska and
Hawaii; also excluding the Territories of Puerto Rico and the Virgin Islands, and the District of Columbia) was conducted in April 2009. Specific information about aquifers was queried to determine which aquifers were supplying water to domestic wells. In total, there were more than 443,300 domestic wells in NWIS databases in the lower 48 States. About 65 percent of the total domestic wells (almost 291,000) had information that identified a principal aquifer. These data were used to construct a county database with the percentage of wells in each county that withdraw water from 1 of the 20 aquifers. The percentage of wells in each county that withdraw water from any of the 20 aquifers was used to allocate withdrawals and population served to those aquifers.

NWIS databases are not an entirely complete or current inventory of all domestic wells in each state. The databases store a compilation of wells that were inventoried as part of projects and studies conducted in each state over time. For example, if groundwater studies in a state focused more intensely on one particular aquifer than another, or on wells in one particular part of a state rather than across all areas, the database will reflect a bias and cannot be expected to reflect a completely accurate representation of all aquifers or all areas of a state. However, lacking any other nationally consistent and readily available sources, the NWIS databases were the best source of information for this study and in many cases, the aquifers or areas of a state that are the focus of studies also are the important sources of drinking water.

A few states did not have domestic well information in NWIS and thus aquifer information regarding which aquifer to allocate withdrawal and population served data was not readily available. This lack of available information does not mean that these counties do not have domestic wells, but does indicate where NWIS had deficient information that would otherwise have been used in this study. Counties lacking domestic well information in NWIS at the time of the retrievals (April 2009) are shown in figure 2. If a county did not have domestic well information in NWIS, then the domestic withdrawals and population served for that county were allocated to any of the 20 aquifers based on the percentage of the county's geographic area that was coincident with the geographic area of the aquifer. A simple area-weighted allocation was used to calculate withdrawals and population served in those areas based on the percentage of area and the county data from NWUIP.

\section{Results}

Total self-supplied domestic withdrawals and population served for the 20 aquifers are summarized in tables 1-3. The 20 aquifers represent about 63 percent of the total selfsupplied domestic groundwater withdrawals and about 61 percent of the total population served by those withdrawals in the United States for calendar year 2005. The Glacial aquifer system (table 1) had the largest withdrawals and supplied the 


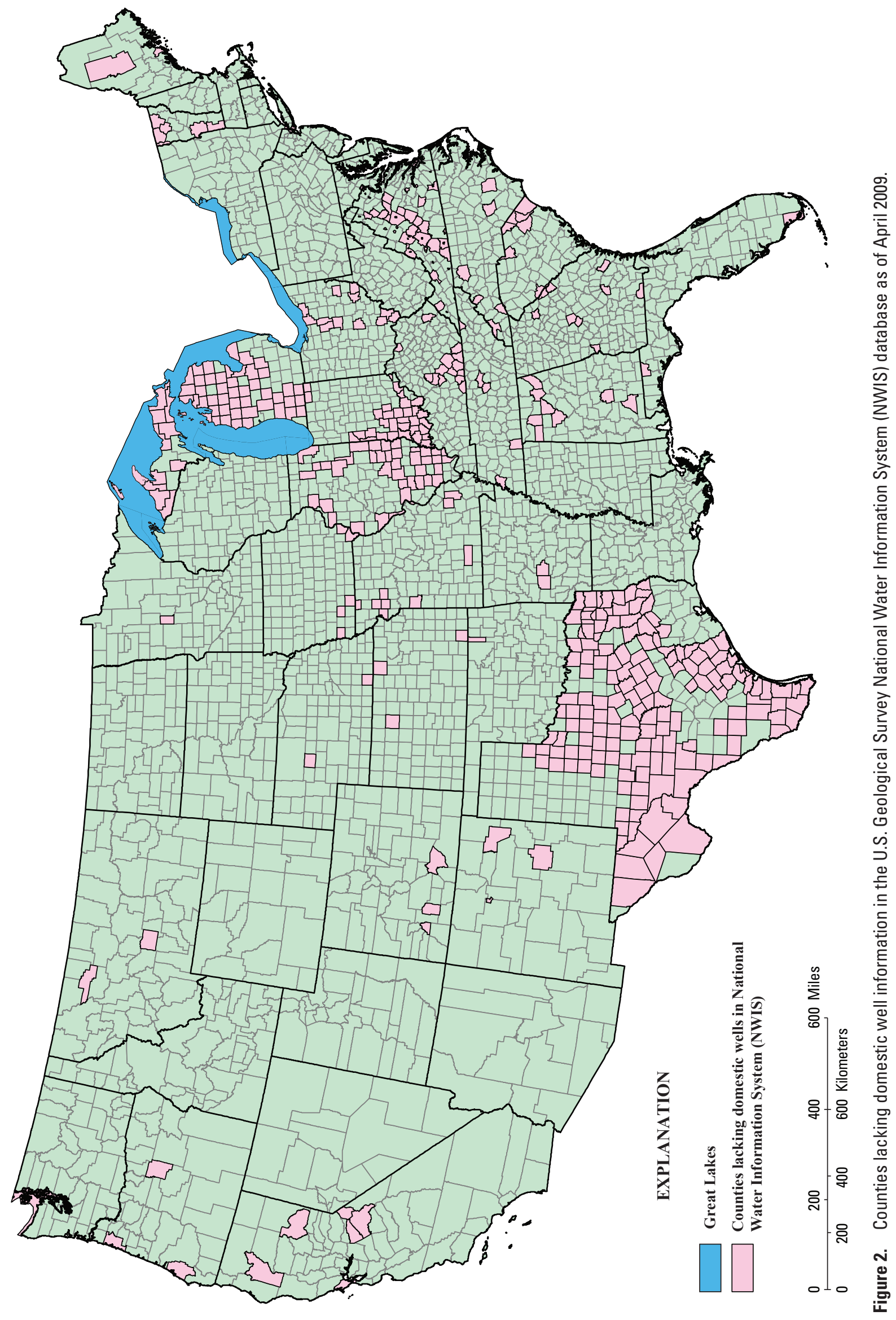


most people among all the 20 aquifers. The Glacial aquifer system also supplied the most water to public-supply systems in 2000 (Maupin and Barber, 2005). The four aquifers with the largest withdrawals and the largest population served were the Glacial aquifer system, Piedmont and Blue Ridge crystalline and carbonate-rock aquifers, the Floridan aquifer system and the overlying Surficial aquifer system, and the Northern Atlantic Coastal Plain aquifer system. Combined, these four aquifers accounted for more than 60 percent of the total self-supplied withdrawals and about 66 percent of the total population served from all 20 aquifers. The daily per-capita use rate, in gallons per-capita per day (gpcd) is shown in table 1 . These values range from about $312 \mathrm{gpcd}$ for the Central Valley aquifer system, to about 59 gpcd for the Cambrian-Ordovician aquifer system. Generally, the daily per-capita use rate varies in accordance with general climatic regions. Dry and hot regions, such as the Southwest, generally exhibit higher per-capita use rates than cooler, wet regions.

Data for self-supplied domestic withdrawals and population served for the 20 aquifers, by state, are shown in tables 2 and $\underline{3}$, respectively. Three aquifers in four states accounted for the largest withdrawals (greater than
$100 \mathrm{Mgal} / \mathrm{d}$ ) - the Glacial aquifer system in Michigan (184 Mgal/d) and Indiana (124 Mgal/d), the Floridan aquifer system combined with the overlaying Surficial aquifer system in Florida (168 Mgal/d), and the Central Valley aquifer system in California (136 Mgal/d) (table 2). More than 1 million people in Florida, Michigan, and Indiana used groundwater from the Floridan and overlying Surficial aquifer systems, or the Glacial aquifer system, respectively (table 3). Total withdrawals and total population served, by state for the 20 aquifers, are shown in tables 2 and $\underline{3}$, along with the state total withdrawals and population served from the 2005 compilation (Kenny and others, 2009). These data provide a reference point from which to determine the percentage of the entire state's self-supplied domestic use and population served that is accounted for by the 20 aquifers. Self-supplied domestic withdrawals and population served in six states are completely provided by four aquifers as follows: Hawaii is supplied entirely by the Hawaiian volcanic-rock aquifers, Indiana is supplied entirely by the Glacial aquifer system, and Maine, New Hampshire, Rhode Island, and Vermont each are entirely supplied by the Glacial aquifer system and the New England crystalline-rock aquifers.

Table 1. Summary of total self-supplied domestic groundwater withdrawals and total population served for 20 aquifers during calendar year 2005.

[Shading indicates combination of principal aquifer. Glacial aquifer system is aquifer composed of glacial deposits. Figures may not sum to totals because of independent rounding. Abbreviations: Mgal/d, million gallons per day; gpcd, gallons per capita per day]

\begin{tabular}{|c|c|c|c|}
\hline Principal aquifer name & $\begin{array}{c}\text { Groundwater } \\
\text { withdrawals by } \\
\text { principal aquifers } \\
\text { (Mgal/d) }\end{array}$ & $\begin{array}{l}\text { Population served } \\
\text { (thousands) }\end{array}$ & $\begin{array}{l}\text { Daily per-capita use } \\
\text { (gpcd) }\end{array}$ \\
\hline Glacial aquifer system & 741 & 8,820 & 84.0 \\
\hline Piedmont and Blue Ridge carbonate- and crystalline-rock aquifers & 360 & 4,610 & 78.2 \\
\hline Floridan aquifer system and the overlying Surficial aquifer system & 212 & 1,960 & 108 \\
\hline Northern Atlantic Coastal Plain aquifer system & 140 & 1,820 & 76.8 \\
\hline Central Valley aquifer system & 136 & 437 & 312 \\
\hline Coastal Lowlands aquifer system & 112 & 1,320 & 84.6 \\
\hline Valley and Ridge aquifers & 110 & 1,540 & 72.0 \\
\hline Mississippi Embayment-Texas Coastal Uplands aquifer system & 100 & 972 & 103 \\
\hline Early Mesozoic basin aquifers & 80.5 & 1,150 & 69.7 \\
\hline Basin and Range basin-fill and carbonate aquifers & 63.6 & 432 & 147 \\
\hline Edwards-Trinity aquifer system & 63.4 & 552 & 114 \\
\hline New England crystalline-rock aquifers & 48.7 & 642 & 75.8 \\
\hline Cambrian-Ordovician aquifer system & 41.2 & 702 & 58.8 \\
\hline California Coastal Basin aquifers & 35.5 & 310 & 114 \\
\hline Snake River basin-fill and basaltic-rock aquifers & 34.0 & 168 & 201 \\
\hline Columbia Plateau basin-fill and basaltic-rock aquifers & 33.4 & 258 & 129 \\
\hline Rio Grande aquifer system & 18.0 & 175 & 103 \\
\hline Hawaiian volcanic-rock aquifers & 12.2 & 74.0 & 164 \\
\hline Biscayne aquifer & 3.44 & 36.1 & 95.2 \\
\hline Denver basin aquifer system & 3.22 & 26.8 & 120 \\
\hline TOTAL & 2,340 & 26,000 & 90.3 \\
\hline
\end{tabular}


Table 2. Estimated self-supplied domestic groundwater withdrawals by state and aquifer for calendar year 2005.

[Withdrawals are in million gallons per day (Mgal/d). Shading indicates combination of principal aquifer. Glacial aquifer system is aquifer composed of glacial deposits. Asterisk $\left(^{*}\right)$ next to a state name indicates data provided by water-use specialists at the U.S. Geological Survey Water Science Center. Values for total self-supplied domestic groundwater withdrawals are from Kenny and others (2009). Figures may not sum to totals because of independent rounding]

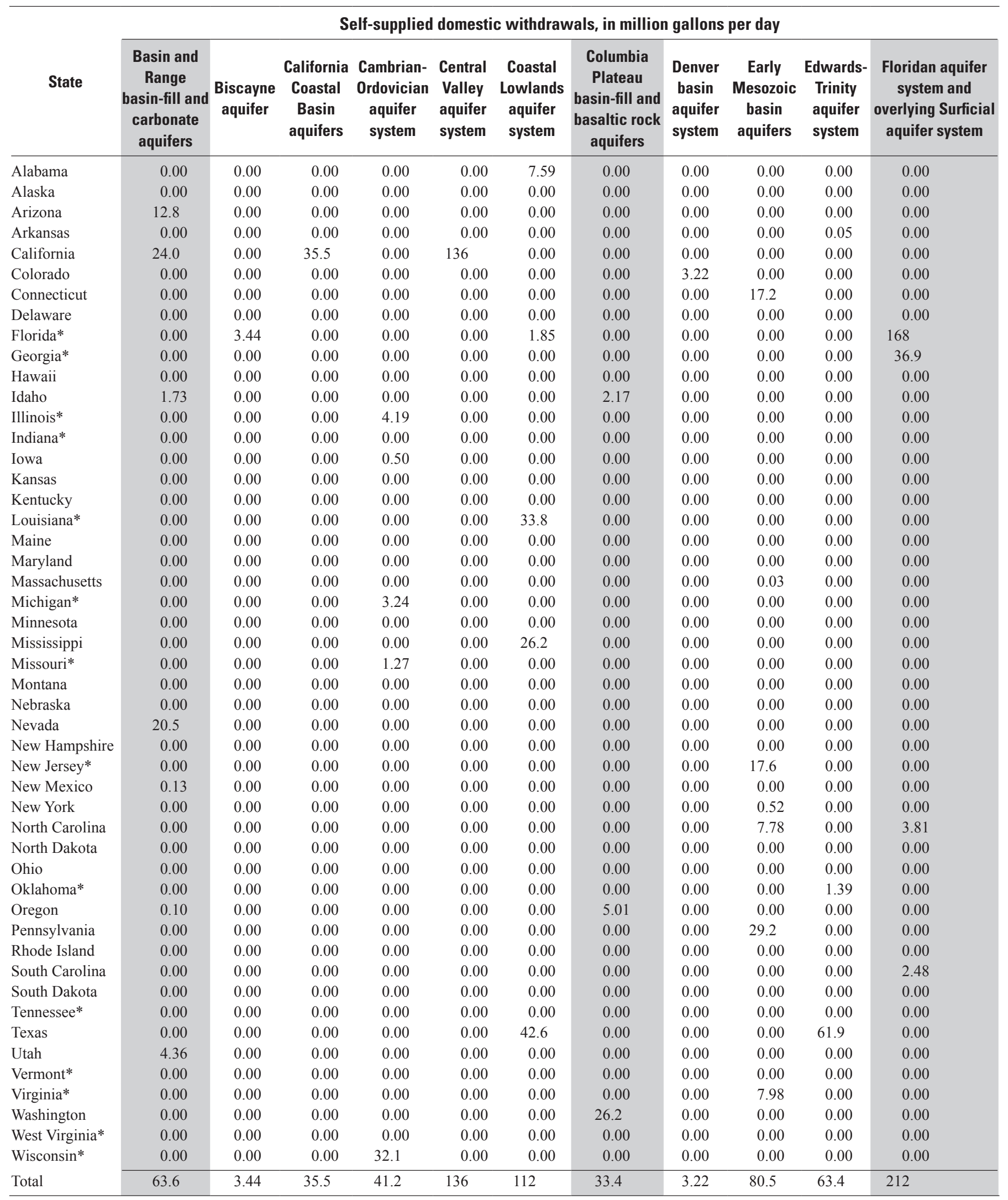


Table 2. Estimated self-supplied domestic groundwater withdrawals by state and aquifer for calendar year 2005.—Continued

[Withdrawals are in million gallons per day (Mgal/d). Shading indicates combination of principal aquifer. Glacial aquifer system is aquifer composed of glacial deposits. Asterisk $\left(^{*}\right)$ next to a state name indicates data provided by water-use specialists at the U.S. Geological Survey Water Science Center. Values for total self-supplied domestic groundwater withdrawals are from Kenny and others (2009). Figures may not sum to totals because of independent rounding]

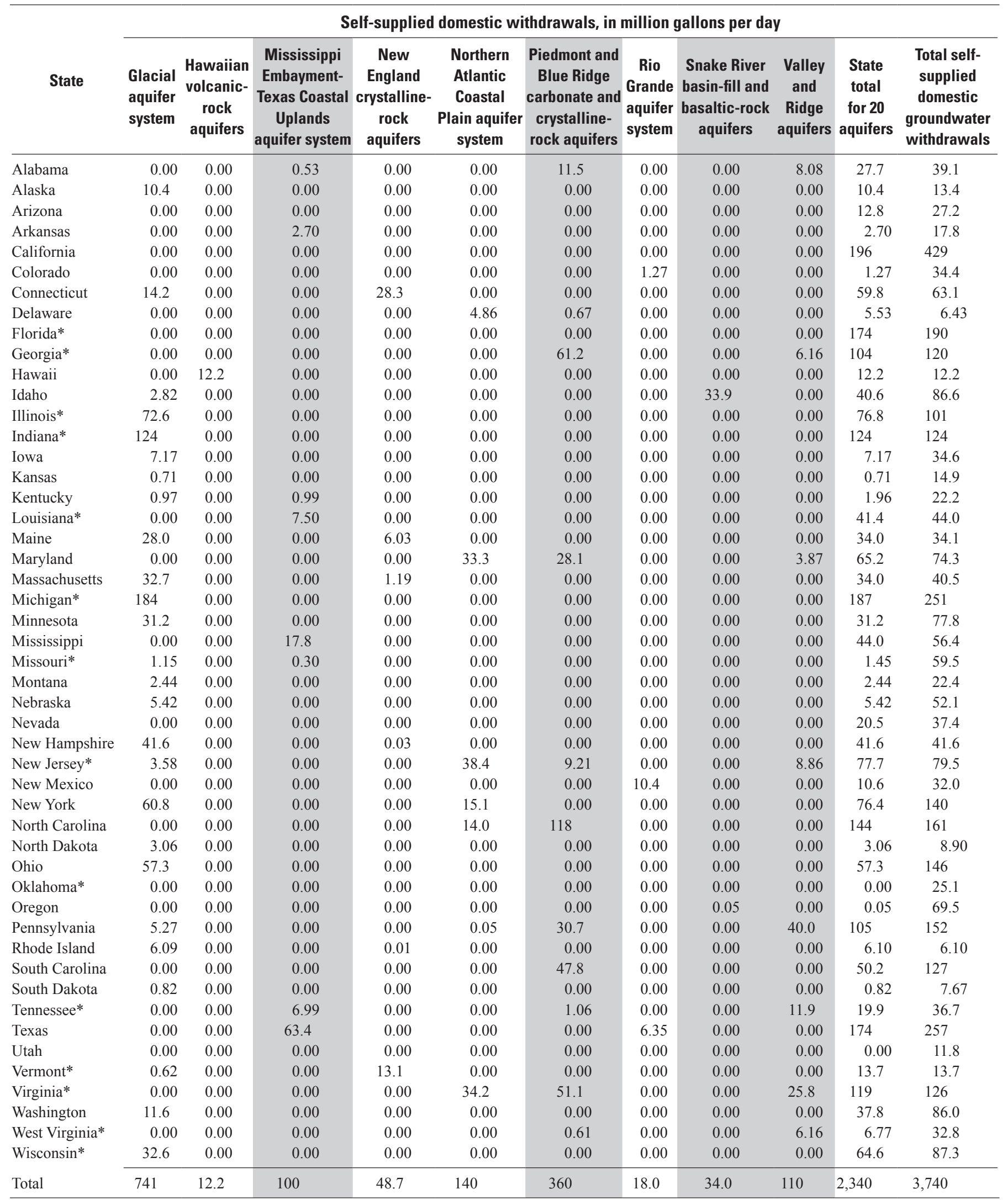


Table 3. Estimated self-supplied domestic population served by state and aquifer for calendar year 2005.

[Self-supplied domestic population in thousands. Shading indicates combination of principal aquifer. Glacial aquifer system is aquifer composed of glacial deposits. Asterisk $\left(^{*}\right)$ next to a state name indicates data provided by water-use specialists at the U.S. Geological Survey Water Science Center. Values for total self-supply domestic groundwater served are from Kenny and others (2009). Figures may not sum to totals because of independent rounding]

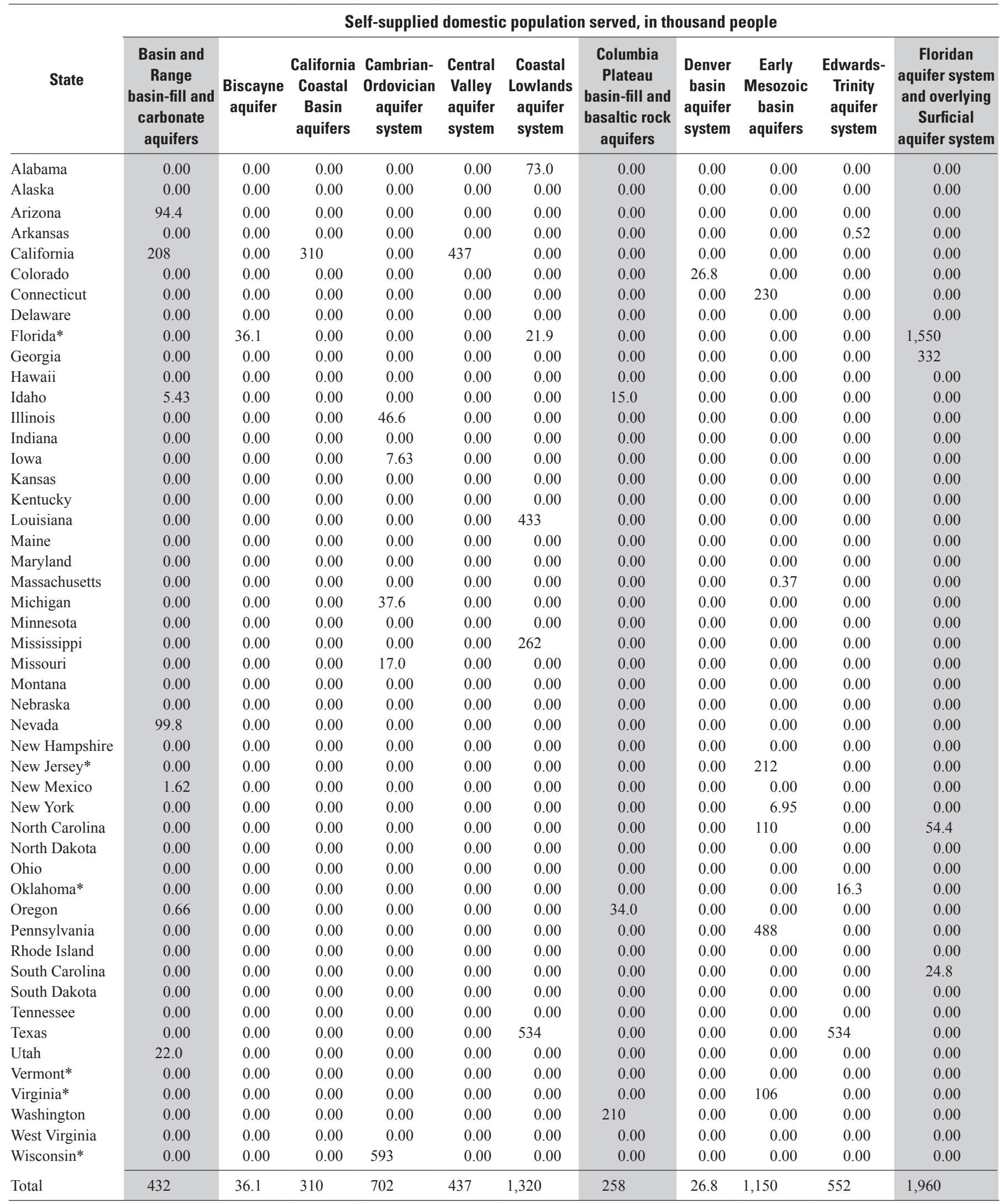


Table 3. Estimated self-supplied domestic population served by state and aquifer for calendar year 2005.—Continued

[Self-supplied domestic population in thousands. Shading indicates combination of principal aquifer. Glacial aquifer system is aquifer composed of glacial deposits. Asterisk (*) next to a state name indicates data provided by water-use specialists at the U.S. Geological Survey Water Science Center. Values for total self-supply domestic groundwater served are from Kenny and others (2009). Figures may not sum to totals because of independent rounding.]

\begin{tabular}{|c|c|c|c|c|c|c|c|c|c|c|c|}
\hline State & \multicolumn{11}{|c|}{ Self-supplied domestic population served, in thousand people } \\
\hline Alabama & 0.00 & 0.00 & 7.18 & 0.00 & 0.00 & 216 & 0.00 & 0.00 & 51.4 & 348 & 521 \\
\hline Arizona & 0.00 & 0.00 & 0.00 & 0.00 & 0.00 & 0.00 & 0.00 & 0.00 & 0.00 & 94.4 & 218 \\
\hline Arkansas & 0.00 & 0.00 & 30.2 & 0.00 & 0.00 & 0.00 & 0.00 & 0.00 & 0.00 & 30.7 & 200 \\
\hline California & 0.00 & 0.00 & 0.00 & 0.00 & 0.00 & 0.00 & 0.00 & 0.00 & 0.00 & 955 & 2,710 \\
\hline Colorado & 0.00 & 0.00 & 0.00 & 0.00 & 0.00 & 0.00 & 8.36 & 0.00 & 0.00 & 35.2 & 299 \\
\hline Connecticut & 190 & 0.00 & 0.00 & 378 & 0.00 & 0.00 & 0.00 & 0.00 & 0.00 & 798 & 841 \\
\hline Delaware & 0.00 & 0.00 & 0.00 & 0.00 & 68.8 & 8.30 & 0.00 & 0.00 & 0.00 & 77.0 & 80.4 \\
\hline Illinois & 806 & 0.00 & 0.00 & 0.00 & 0.00 & 0.00 & 0.00 & 0.00 & 0.00 & 853 & 1,130 \\
\hline Indiana & 1,620 & 0.00 & 0.00 & 0.00 & 0.00 & 0.00 & 0.00 & 0.00 & 0.00 & 1,620 & 1,630 \\
\hline Iowa & 110 & 0.00 & 0.00 & 0.00 & 0.00 & 0.00 & 0.00 & 0.00 & 0.00 & 118 & 531 \\
\hline Kansas & 9.66 & 0.00 & 0.00 & 0.00 & 0.00 & 0.00 & 0.00 & 0.00 & 0.00 & 9.66 & 149 \\
\hline Kentucky & 19.4 & 0.00 & 19.6 & 0.00 & 0.00 & 0.00 & 0.00 & 0.00 & 0.00 & 39.1 & 696 \\
\hline Louisiana & 0.00 & 0.00 & 80.5 & 0.00 & 0.00 & 0.00 & 0.00 & 0.00 & 0.00 & 514 & 551 \\
\hline Maine & 505 & 0.00 & 0.00 & 70.1 & 0.00 & 0.00 & 0.00 & 0.00 & 0.00 & 575 & 575 \\
\hline Maryland & 0.00 & 0.00 & 0.00 & 0.00 & 416 & 351 & 0.00 & 0.00 & 36.3 & 803 & 929 \\
\hline Massachusetts & 418 & 0.00 & 0.00 & 16.6 & 0.00 & 0.00 & 0.00 & 0.00 & 0.00 & 436 & 527 \\
\hline Michigan & 1,200 & 0.00 & 0.00 & 0.00 & 0.00 & 0.00 & 0.00 & 0.00 & 0.00 & 1,240 & 2,910 \\
\hline Minnesota & 446 & 0.00 & 0.00 & 0.00 & 0.00 & 0.00 & 0.00 & 0.00 & 0.00 & 446 & 1,110 \\
\hline Mississippi & 0.00 & 0.00 & 177 & 0.00 & 0.00 & 0.00 & 0.00 & 0.00 & 0.00 & 440 & 555 \\
\hline New York & 810 & 0.00 & 0.00 & 0.00 & 202 & 0.00 & 0.00 & 0.00 & 0.00 & 1,020 & 1,870 \\
\hline North Carolina & 0.00 & 0.00 & 0.00 & 0.00 & 199 & 1,690 & 0.00 & 0.00 & 0.00 & 2,060 & 2,300 \\
\hline North Dakota & 36.6 & 0.00 & 0.00 & 0.00 & 0.00 & 0.00 & 0.00 & 0.00 & 0.00 & 36.6 & 105 \\
\hline Ohio & 764 & 0.00 & 0.00 & 0.00 & 0.00 & 0.00 & 0.00 & 0.00 & 0.00 & 764 & 1,990 \\
\hline Oklahoma* & 0.00 & 0.00 & 0.00 & 0.00 & 0.00 & 0.00 & 0.00 & 0.00 & 0.00 & 16.3 & 295 \\
\hline Oregon & 0.00 & 0.00 & 0.00 & 0.00 & 0.00 & 0.00 & 0.00 & 0.30 & 0.00 & 35.0 & 707 \\
\hline Pennsylvania & 87.8 & 0.00 & 0.00 & 0.00 & 0.77 & 517 & 0.00 & 0.00 & 667 & 1,760 & 2,540 \\
\hline Rhode Island & 85.7 & 0.00 & 0.00 & 0.19 & 0.00 & 0.00 & 0.00 & 0.00 & 0.00 & 86.0 & 85.9 \\
\hline South Carolina & 0.00 & 0.00 & 0.00 & 0.00 & 0.00 & 478 & 0.00 & 0.00 & 0.00 & 502 & 1,270 \\
\hline South Dakota & 11.9 & 0.00 & 0.00 & 0.00 & 0.00 & 0.00 & 0.00 & 0.00 & 0.00 & 12.0 & 110 \\
\hline Tennessee & 0.00 & 0.00 & 96.8 & 0.00 & 0.00 & 14.6 & 0.00 & 0.00 & 164 & 276 & 509 \\
\hline Texas & 0.00 & 0.00 & 552 & 0.00 & 0.00 & 0.00 & 55.2 & 0.00 & 0.00 & 1,680 & 2,230 \\
\hline Utah & 0.00 & 0.00 & 0.00 & 0.00 & 0.00 & 0.00 & 0.00 & 0.00 & 0.00 & 22.0 & 68.5 \\
\hline Vermont* & 7.92 & 0.00 & 0.00 & 178 & 0.00 & 0.00 & 0.00 & 0.00 & 0.00 & 185 & 185 \\
\hline Virginia* & 0.00 & 0.00 & 0.00 & 0.00 & 455 & 734 & 0.00 & 0.00 & 344 & 1,640 & 1,680 \\
\hline Washington & 160 & 0.00 & 0.00 & 0.00 & 0.00 & 0.00 & 0.00 & 0.00 & 0.00 & 370 & 904 \\
\hline West Virginia & 0.00 & 0.00 & 0.00 & 0.00 & 0.00 & 1.00 & 0.00 & 0.00 & 77.6 & 78.6 & 420 \\
\hline Wisconsin* & 652 & 0.00 & 0.00 & 0.00 & 0.00 & 0.00 & 0.00 & 0.00 & 0.00 & 1,240 & 1,670 \\
\hline Total & 8,820 & 74.0 & 972 & 642 & 1,820 & 4,610 & 175 & 168 & 1,540 & 26,000 & 42,900 \\
\hline
\end{tabular}




\section{Summary}

This report represents the most recent assessment of estimated self-supplied domestic withdrawals and population served for 20 aquifers in the United States. These data were compiled to support regional National Water-Quality Assessment Program studies, which focuses on groundwater quality of principal aquifers in the U.S., which are important sources of water to both public supply and private domestic uses. Estimated groundwater withdrawals for public-supply, self-supplied industrial, and irrigation uses from more than 60 principal aquifers were compiled using 2000 data, but estimates for aquifer withdrawal or populations served are not available for the self-supplied domestic uses. This report summarizes the most currently available (calendar year 2005) water-use estimates from the National Water Use Information Program for self-supplied domestic groundwater withdrawals and population served allocated to 20 aquifers.

Estimates of withdrawals from the 20 aquifers were provided by USGS water-use specialists, or were determined using well information available in USGS databases, or geographic areaweighted processes.

The 20 aquifers represent about 63 percent of the total self-supplied domestic groundwater withdrawals, and about 61 percent of the total population served by those withdrawals in the United States for calendar year 2005. The Glacial aquifer system had the largest withdrawals and supplied the most people among all the aquifers. The four aquifers with the largest withdrawals and the largest population served were the Glacial aquifer system, Piedmont and Blue Ridge crystalline and carbonate-rock aquifers, the Floridan aquifer system and the overlying Surficial aquifer system, and the Northern Atlantic Coastal Plain aquifer system. Combined, these four aquifers accounted for more than 60 percent of the total self-supplied domestic withdrawals, and about 66 percent of the total population served by those withdrawals from the 20 aquifers. Three aquifers in four States accounted for the largest withdrawals (greater than $100 \mathrm{Mgal} / \mathrm{d}$ ) - the Glacial aquifer system in Michigan (184 Mgal/d) and Indiana (124 Mgal/d), the Floridan aquifer system combined with the overlaying Surficial aquifer system in Florida (168 Mgal/d), and the Central Valley aquifer system in California (136 Mgal/d). More than 1 million people in Florida, Indiana, and Michigan used groundwater from the Floridan and the overlying Surficial aquifer systems or the Glacial aquifer system. All withdrawals and population served in six states are supplied by four aquifers as follows: Hawaii is supplied entirely by the Hawaiian volcanic-rock aquifers, Indiana is supplied entirely by the Glacial aquifer system, and Maine, New Hampshire, Rhode Island, and Vermont each are supplied entirely by the Glacial aquifer system and the New England crystalline-rock aquifers.

\section{References Cited}

Hutson, S.S., compiler, 2007, Guidelines for preparation of State water-use estimates for 2005: U.S. Geological Survey Techniques and Methods, Book 4, Chap. E1, 28 p. (Also available at http://pubs.usgs.gov/tm/2007/tm4e1.)

Kenny, J.F., Barber, N.L., Hutson, S.S., Linsey, K.S., Lovelace, J.K., and Maupin, M.A., 2009, Estimated use of water in the United States in 2005: U.S. Geological Survey Circular 1344, 52 p. (Also available at http://pubs.usgs.gov/ circ/1344/.)

Lapham, W.W., Hamilton, P.A., and Myers, D.N., 2005, National water-quality assessment program - cycle ii, regional assessments of aquifers: U.S. Geological Survey Fact Sheet 2005-3013, 4 p. (Also available at http://pubs. usgs.gov/fs/2005/3013/.)

Marella, R.L., 2009, Water withdrawals, use, and trends in Florida, 2005: U.S. Geological Survey Scientific Investigations Report 2009-5125, 49 p. (Also available at http://pubs.usgs.gov/sir/2009/5125/.)

Maupin, M.A., and Barber, N.L., 2005, Estimated withdrawals from principal aquifers in the United States, 2000: U.S. Geological Survey Circular 1279, 46 p. (Also available at http://pubs.usgs.gov/circ/2005/1279/.)

National Water-Quality Assessment Program (2010) WaterQuality Assessments of Principal Aquifers: U.S. Geological Survey website, accessed July 14, 2010, at http://water.usgs. gov/nawqa/studies/praq/.

Pope, J.P., McFarland, E.R., and Banks, R.B., 2008, Private domestic well characteristics and the distribution of domestic withdrawals among aquifers in the Virginia Coastal Plain: U.S. Geological Survey Scientific Investigations Report 2007-5250, 47 p. (Also available at http://pubs.usgs.gov/sir/2007/5250/.)

Tortorelli, R.L., 2009, Water use in Oklahoma, 1950-2005: U.S. Geological Survey Scientific Investigations Report 2009-5212, 49 p. (Also available at http://pubs.usgs.gov/ $\underline{\operatorname{sir} / 2009 / 5212 / .}$.)

U.S. Geological Survey, 2003, Principal aquifers, in National Atlas of the United States of America, 1 sheet, accessed February 26, 2010, at http://nationalatlas.gov/mld/aquifrp. $\underline{\mathrm{html}}$. 
Publishing support provided by the U.S. Geological Survey

Publishing Network, Tacoma Publishing Service Center

For more information concerning the research in this report, contact the Director, Idaho Water Science Center

U.S. Geological Survey

230 Collins Road

Boise, Idaho 83702

http://id.water.usgs.gov 


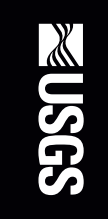

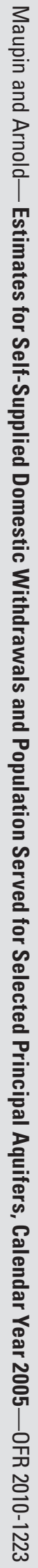

